be provisionally referred to as the 'mild yellow-edge' virus. When a Royal Sovereign plant infected with one of these viruses is grafted
to one infected with the other, both plants develop severe yellow-edge to one infecte

It follows from these observations that yellow-edge is caused by the combined action of two distinct viruses (the mild crinkle virus and the mild yellow-edge virus), which can be separated by making

This conclusion does not, however, exclude the possibility that other viruses or combinations of viruses may also cause yellow-edge. whith I have also found that a persistent virus (probably identica with the persistent virus of Wood and Whitehead) can be isolated from plants infected with 'severe crinkle'. 'This virus is transmitted by $C$. fragariae after an infection-feeding period of ten days, persists in the vector for several days and, by itself, produces symptoms of the severe crinkle type on Royal Sovereign. The combination of this virus with the persistent virus isolated from a plant infected with yellow-edge, as described above, also produces severe yellow-edge.

Two etiologically distinct types of yellow-edge have therefore been synthesized, each produced by a pair of viruses, the pairs having the mild yellow-edge virus in common. The second virus is, in one case, of the mild crinkle type and, in the other, of the severe crinkle type. The frequent occurrence of crinkle in association with yellow-edge has already been noted in grafting experiments ${ }^{3}$, but the oblig
nature of this association had not previously been demonstrated.

East Malling Research Station, IAN W. PRentich Maidstone, Kent.

1 Prentice, J. W., and Harris, R. V., Ann. Appl. Biol., 33, 50 (1946).

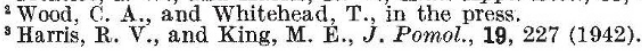

\section{Magnesium Chlorosis of Tomatoes}

THE summary in Nature of the paper by Walsh and Clarke ${ }^{2}$ directs attention to the methods of treating tomato plants a ffected by induced magnesium deficiency. The paper emphasizes the importance in this connexion of the potash level in the soil, a relationship which was previously described by Cromwell and Hunter ${ }^{3}$, and a review of the position may be timely.

Jones, Nicholas and Wallace 4 , and Jones, Nicholas, Wallace and Jefferiss ${ }^{5}$, stated that good control of magnesium deficiency in tomatoes was obtained by heavy applications of magnesium sulphate to the soil. Similar treatments given during several years in south-western Scotland have been ineffective.

In sand-culture experiments conducted in this College, absorption of magnesium decreased with increasing concentration of the solution in which the plants were growing; this effect of concentration was as important as was the ratio of jons in the solution: when the solution was relatively concentrated and also the ratio of potassium to magnesium in it was high, then the absorption of magnesium was most restricted and the chlorosis was most severe. The conductivity of soil surrounding chlorotic plants was always found to be high, and nsually to be higher than that of neighbouring soil bearing healthy or less severely affected plants. neighbouring soil bearing healthy or soluble salts in the soil would thus probably be harmfully increased by applications of magnesium salts.

It has already been pointed out by Cromwell and Hunter ${ }^{3}$ that this type of chlorosis may also be caused by factors other than the this type of chlorosis may

potash status of the soil. in tomatoes was associated particularly with the use of potassium sulphate as a fertilizer, though excessive applications of other potassic fertilizers also induced the deficiency. The effect of potassium sulphate probably arises from the different rates of absorption
of its ions. The chlorosis was not increased by raising the sulphate of its ions. The chlorosis was not increased by raising the sulphate by means of sodium sulphate or calcium sulphate, the amounts of other fertilizers applied being adjusted to keep the concentration of soluble salts approximately constant.

That control of the chlorosis may be obtained by repeatedly spraying the foliage with magnesium sulphate solution has been reported by Jones, Nicholas, Wallace and Jefferiss ${ }^{5}$, and control was obtained in this area when the plants were sprayed sufficiently often. It seems unlikely that spraying treatment will have practical value in the West of Scotland College area.

Several different types of soil cultivation for glasshouse tomatoes have been investigated at the College, but none was found effective in controlling the chlorosis.

Results obtained this season by, for example, early mulching with farmyard manure or peat suggest, however, that an encouragement of secondary root production may go far to offset the conditions under which induced magnesium deficiency a ppears.

This work has been done by co-operation between the Departments of Chemistry and Horticulture at the College.

Until new cultural methods have been fully investigated, the cure for induced magnesium deficiency, if it persists when the potash
dressings are kept as low as possible, seems to lie in resoiling, and, taking into account the other advantages of resoiling, this may be economic.

Department of Chemistry

J. G. HUNTER

West of Scotland Agricultural College, Glasgow, C.2.
May 29.

1 Nature, 156, 702 (1946)

Walsh, T., and Clarke, E. J., J. Roy. Hort. Soc., 70, Pt. 7 (1945) 3 Cromwell, B. T., and Hunter, J. G., Nature, 150, 606 (1942)

Jones, J. O., Nicholas, D. J., and Wallace, T., Ann. Rep. Agric.

- Jones, J. O., Nicholas, D. J., Wallace, T., and Jefferiss," A., Ann. Rep. Agric. and Hort. Res.' Stat., Long Ashton, 61 (1944).

\section{Aphosphorosis and Phosphate Reserves}

THE solid rock substratum of County Offaly is almost exclusively Carboniferous limestone without igneous intrusions, overiain by phorosis pates of bog land and glacial limestone drift. The aphosphorosis in Offaly cattle described by Prof. E. J. Sheehy ${ }^{1}$ may be a permanent characteristic of certain areas : but during recent years the annual loss of tricalcium phosphate through the export of cattle from Eire has been of the order of 25,000 tons $^{2}$ in contrast to the $17,000^{3,4}$
mentioned for New Zealand. This has not been restored to the soil. The normal imports, seriously reduced during the war period, are The normal imports, seriously reduced during the war period, are about four times as great. The drain on phosphorus from the soil
is also being considerably aggravated by increased tillage, although is also being considerably aggravated by increased tillage, although the emergency production of phosphorite from West Clare ${ }^{6}$ has offset the rate of release of phosphorus from the rock via the soil into the vegetation can no longer keep pace with the demand, and where vegetation can no longer keep pace with the demand, and where accordingly there will be created a deficiency in available phosphorus for years, unless it is artificially replaced. Significantly, this is reported would be of less account, but for the constant irreversible loss through would be of less account,

The phosphorus balance-sheets of those countries now exporting food will evidently require careful watching

The somewhat unusual Carboniferous phosphorite deposits of West Clare, on which a preliminary note ${ }^{5}$ was published in 1942 , are to be described in greater detail elsewhere. They occur as thin flat lenses interbedded in black shales a few feet above the top of the Upper Carboniferous limestone, and are considered to have been deposited in shallow salt water not far from the land surface which provided the first outrush of Millstone Grit sediments into the crinoidal limestone sea. The shales were associated by Wheelton Hind ${ }^{6}$ with equivalent beds in England and at Chokier in Belgium. The phosphorite lenses are by no means easy to locate, and while search in Ireland has been unsuccessful outside Co. Clare, it may still be worth ticular horizon in more distant areas.

\section{Hume Street,}

D. W. BISHOPP

April 23 .

'Sheehy, E. J., Nature, 157, 440 (1945).

2 Bishopp, D. W., "The Natural Resources of Ireland" (Sir Robt. Kane Centenary Symposium, Royal Dublin Society, 1944) 3 Armstrong, E. F., Nature, 150,453 (1942).

¿ Jenkins, S. H., and Lockett, W. T., Nature, 151, 306 (1943).

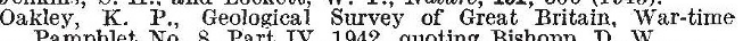
Pamphlet No. 8, Part IV, 1942, quoting Bishopp, D. W. - Wheelton Hind, Proc. Roy. Irish Acad., 25, Sect. B. No. 4 (1905).

\section{A New $R h$ Allelomorph}

A CELI, sample from a blood donor ( $A$ be - - ) was found to be of Group $O R h_{r} r h$. That is to say, the blood was agglutinated by anti- $c$, anti-E and anti-e, but not by anti-C sera: the resnlt with anti- $D$ serum was variable. While the agglutination of this blood sample by certain anti- $D$ sera was strong, using others it was weak, with only a few cells being clumped, and some gave completely negative results. This suggested the presence of a new allele $D U$ at Fisher's $D-d$ locus. The donor's cells would, therefore, be cDVE/cde. This hypothesis is supported first by an examination of the donor's family, of the same type, and secondly by the discovery of two cell samples of the type CDVe/cde. and one of type $C D U e / C d e^{1}$.

\begin{tabular}{|c|c|c|c|c|c|c|c|}
\hline Cells & \multicolumn{7}{|c|}{ Dilution of serum } \\
\hline & \multicolumn{7}{|c|}{ Anti- $D$ (i) } \\
\hline & 1 & 2 & 4 & 816 & 32 & 64 & 128 \\
\hline$R_{2^{r}} \cdot(A b e--)$ & + & + & + & + & + & $\overline{1}$ & - \\
\hline$R_{2} r,(B a--)$ & t & + & + & $\stackrel{+}{\text { Anti- } D} D_{(\mathrm{ii})}^{+}$ & + & + & - \\
\hline$R_{2} r \cdot(A b e-)$ & $\bar{t}$ & $\overline{+}$ & $\overline{+}$ & $\overline{1}$ & $\vec{i}$ & $\overline{1}$ & - \\
\hline$R_{2} r \cdot(B a-)$ & + & + & + & + & + & + & - \\
\hline
\end{tabular}

Thirty-two strong anti- $D$ sera were tested against the donor's cells. Twelve tests were found to be positive, exhibiting agglutination of variable intensity. Twenty of the sera completely failed to agglutinate the cells, but some contained blocking antibodies to the donor's table. Anti- $D$ blocking antibody will apparently prevent the agglutination of the donor's cells by anti- $D U$ agglutinins.

tion of the donor's cells by anti- $D U$ agglutinins. Adsorption of anti- $D+$ anti- $D U$ has not resulted in the production Adsorption of anti- $D+$ anti- $D U$ has not resulted in the production of a pure anti- $D U$ agglutinin. Attempted immunization of two persons no agglutinins in the serum) with the donor's cells failed to produce n anti- $D U$ serum or to increase the titre of anti- $D U$.

The above findings can only be properly assessed in terms of Fisher's hypothesis. It is especially helpful to consider closely the analogy with $C^{w 1,2}$. In this case it was shown that previously known anti-C sera were of two classes, a pure anti- $C$ and one consisting of mix-
tures of anti- $C$ and anti- $C^{20}$. The ability of the antigen $C$ to provoke either a pure anti- $C$ serum or anti- $C+$ anti- $C^{w}$ showed a chemical similarity between the antigens and was perhaps in favour of $C^{w}$ being an allele of $C$. Furthermore, the antigen $C^{w}$ was shown to be inherited as part of a complex $C^{w} D e$. The reactions of individual heterozygotes such as $C^{w} D e / c d e$ could be interpreted in terms of $C^{w}$ being an allele of $C$, but could equally be due to an antigen produced by a fourth closely linked locus (say, $F$ ). It could, however, be shown
that as the new antigen was passed on from one generation to the 